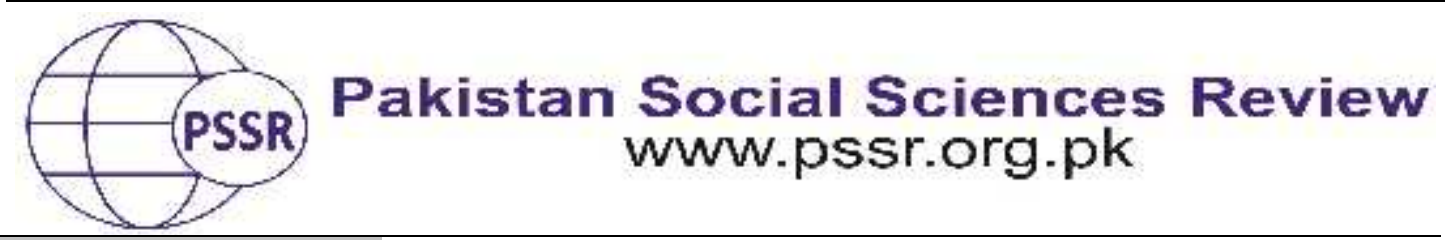

RESEARCH PAPER

\title{
Ecriture Feminine Reconfiguration of Black Woman's Identity in Morrison's Beloved: A Poststructural Feminist Critique
}

\author{
Mumtaz Ahmad ${ }^{1}$ Dr. Ghulam Murtaza ${ }^{2}$ Qasim Shafiq ${ }^{3}$
}

1. Assistant Professor, Principal Govt. Guru Nanak Postgraduate College, Nankana Sahib, Punjab, Pakistan

2. Assistant Professor, Department of English, Government College University Faisalabad, Punjab, Pakistan

3. Ph.D. Scholar, Department of English, National University of Modern Languages, Islamabad, Pakistan

\begin{tabular}{|c|c|}
\hline PAI & \\
\hline 2020 & $\begin{array}{l}\text { this a } \\
\text { wome } \\
\text { subjec }\end{array}$ \\
\hline $\begin{array}{l}\text { s: } \\
\text { ican } \\
\text { minine, } \\
\text { ntrism, }\end{array}$ & $\begin{array}{l}\text { connection between Postst } \\
\text { praxis in Afro-American wo } \\
\text { of gendered narratives abou } \\
\text { writers within phallogoce } \\
\text { present research employs }\end{array}$ \\
\hline $\begin{array}{l}\text { onding } \\
\text { rzaa@g }\end{array}$ & $\begin{array}{l}\text { discursive reconstruction of the subjectivities of Afro-American } \\
\text { women in Toni Morrison's Beloved. The analysis employs } \\
\text { stylistic techniques anchored in the poststructural ecriture } \\
\text { feminist theoretical framework proposed by Helene Cixous, the } \\
\text { key French Feminist theorist of the poststructuralist feminist } \\
\text { school of thought }\end{array}$ \\
\hline
\end{tabular}

\section{Introduction}

Black female writers manipulate dominant male discourses' language and use different discursive strategies to (re)configure the category of women. AfroAmerican female writers employ innovative discursive techniques to subvert the dominant culture's oppressive use of language. This article investigates the (re) construction of gender, identity, subjectivity, and nature in Afro-American 'ecriture feminine' through Poststructuralist feminist theoretical paraphernalia. It explores the ways the female novelists from marginalized communities have represented the distinctive cultural female identity of their women by articulating re-evaluative narratives that deconstruct institutionally supported, stereotypically universalized 
black female images imposed upon the black women by the mainstream, white literary intelligentsia. These female writers not only fundamentally depart from the norms of Euro-American stylistic, formal and structural modalities of the narrative and use as an alternative stylistic montage allowing the black oral traditions to overlap with the white normative models but also offer a deconstructive insight into how Euro-American white power structures influence cultural patterns of current behavior and dictate historical perspectives which marginalize, ignore or overlook the significant black perspective.

\section{Literature Review}

Helen Cixous (1975), a French Feminist, defines 'ecriture feminine' as a concept used by women to subvert the oppressive use of language by maledominant cultures. Through écriture feminine, women writers reject and subvert the stereotypical representation of females. Furthermore, their writings lay emphasis on the practice of writing which helps women to liberate themselves from the oppressive cultures (Cixous, 1975). This theory of difference mounted the 'gender politics' (Butler, 1993) which made the black woman think of her identity (hooks, 1981), encouraged her to "gynocriticism" (Showalter, 1977), "womanism" (Walker, 1983), "inappropriated others" (Minh-ha, 1989) and "strategic essentialism" (Gross, 1985) for authenticity in the constitution of sexist differences that, according to Collins (1991) explain how systems of oppression concerning gender, class, and race are interconnected. This identity politics signified how phallogocentric writings kept feeding the concept of 'the eternal feminine' (Beauvoir, 1989) to nourish the sexism hence urged women to have a textual identity (Cixous, 1975; Irigaray, 1985; Kristeva, 1984)

The key characteristic of the term écriture feminine is that it holds a lack of specificity. Feminine writings of Cixous (1975), Irigaray (1985), and Kristeva (1984) entail this message in their writings as well to falsify fixed taboos associated with the female gender. These feminine writings were designed to question the repressive structures of male writings and thoughts characteristic of patriarchal society. Écriture feminine predominantly focuses on the Western discourses that describe man and woman in the form of binary opposition where one is privileged over the other. Masculine is defined as a dominant term in Western discourses and feminine is described as inferior or 'other' as subordinate position. Kristeva, Cixous, and Irigaray argued that masculine discourses are based on phallocentric structures. They have deconstructed and demystified these phallocentric structures that are rooted in language and culture.

Afro-American Feminist, Patricia Hill Collins (1991) is a prominent black theorist whose understanding of Afro-American feminism has been drawn upon to broaden the spectrum of a theoretical framework and especially to incorporate the theoretical perspective of women of the color on the contemporary black women's issues regarding gender, class race and sexuality. Although a number of Afro American scholars and theorists such as bell hooks (1981) have significantly 
contributed to the black Feminist theory and posed challenges and threats to the Western Feminist position, but Patricia Hill Collins (1991) is an eminent AfroAmerican Feminist scholar and theorist whose theorization of contemporary black women's life helps understand the impact of dominant Western patriarchal capitalist power structures upon the black women's life and culture. By juxtaposing the Western and Afro-American theorists' understanding of the patriarchal power structures in which women, particularly black women, have been suppressed and silenced, the article intends to highlight Afro-American female writers' unique articulation of Afro-centric Feminist epistemologies.

Patricia Hill Collins (2002) validates Afro-American women's identity and challenges Western stereotypical images and construction of African American women by stressing upon women to assert their subjectivities by the process of selfactualization through concrete everyday life experiences. These contrastive, selfdefining, images of the black women, according to Collins (2002), will both resist the dehumanizing discursive constructs of the black women perpetrated by the dominant system and counter or even reject internalized psychological oppression that Afro-American women suffer. In her classic work Black Feminist Thought: Knowledge, Consciousness and the Politics of Empowerment, she asserts the value of writing down every day lived experiences and sharing the innermost feelings in confessional mode. She writes "only the willingness to share private and sometimes painful experience can enable women to create a collective description of the world that is truly ours" (Patricia, 2002, p. 16).

bell hooks is another contemporary Afro-American Feminist scholar, well known for her work Ain't I a Woman: Black Women and Feminism (1981), who has come up with the same stance stressing upon African American women to represent the reality of their life from a Feminist standpoint through writing. Her emphasis upon writing as the most valuable way for Afro-Americans and other women of color to represent themselves brings her Feminist stance closer to that of French Feminists such as Cixous (2002) and Kristeva (1984). Sharing her Feminist standpoint with French Feminists, she states her belief in the libratory potential of black women's writing. She affirms that more than any other kind of writing, the writing of frank confessional narratives by black women who are striving for selfactualization and want to become radical subjects are desired as guiding principles, as texts that establish black women's fellowship with one another. Her feminist writings are fundamentally about eliminating sexist oppression inflicted by malecentered cultural order. Observing the racial politics of mainstream Western Feminist theory that excluded and precluded black women from women's liberation movement, she offered through her black feminist masterpiece Feminist Theory: From Margin to Center (1984) a more inclusionary version of Feminist theory that includes diverse voices from the margins. Moving beyond the traditional Western concept of male and female binary, she stressed the essential relationship between gender, class and sex and exposed the intersectional bases of black women's oppression. She categorically states in Feminism is for Everybody (2000) that without male participation 
in the equality struggle, the revolutionary idea of the feminist movement will not progress. Therefore, believing that without finding ways to restructure the existing cultural framework of power rooted in patriarchal and racial superiority, she argued against the separationist ideology of gendered binarism and emphasized the involvement of males in the equality movement.

\section{Theoretical Framework}

Deriving a comparative methodological approach from French feminist Helen Cixous' theoretical insights this project explores within the domain of AfroAmerican literature the nature of the relationship between female subjectivity, body and the language through ways, especially the discursive modes of expression appropriated by Afro-African writers to (re)inscribe the multilayered black hybrid subjectivities of the Afro-American female subjects. Cixous (1975) encouraged women to write since it is as important for them as it is for males. For Cixous, women need to completely own their bodies and experience because they are the only holders of their bodies, not men. The best way to actualize their potential identity is by writing but women were kept away from the process of writing by patriarchy because the act of writing was supposed to be reserved for "great men". Subverting this myth of writing attached with men she invites women to "Write! Write, let no one hold you back, let nothing stop you: not man" (Cixous, 1975, p. 877). This article intends to explore through the analysis of Beloved how Toni Morrison demonstrates the potential of Afro-American 'ecriture feminine' to espouse and incorporate, mold and indigenize, rather than shun or avoid the pervasive influence of the tenets of White/French feminism, a revolutionary theory that seeks the true freedom and empowerment of women irrespective of class, race and color. Within the theoretical framework provided by the White and Non-white female writers belonging to Euro-American and women of the color, this article aims to highlight the significance and contribution of the Afro-American female writing towards broadening the frontiers of what the French Feminist Helene Cixous has termed 'ecriture feminine'. It seeks to propose alternative ways of informed analysis, grounded in discourse and Feminist theories, to evaluate the Afro-American female writers' contribution to 'ecriture feminine'.

\section{Beloved: An Expression of Black Ecriture Feminine}

Beloved, first published in 1987, is Toni Morrison's most widely known and critically acclaimed novel. Morrison dedicated this novel to those sixty million and more African slaves who died in the Middle Passage on an American slave ship. The novel brought Morrison in the limelight when, despite certain controversies regarding its main characters' killing of her daughter to save her from slavery, it won the prestigious Pulitzer Prize in 1988. The novel is inspired by and based upon the life events of an African-American slave, Margret Garner, who escaped tortures of slavery in Kentucky and fled to Ohio, a free state, and subsequently murdered her daughter for fear of her becoming a slave. In Beloved, Morrison, in a language that is intense and evocative, and brilliant and incisive, narrates the poignant tale of the 
pains and pangs of slavery and its traumatic aftermaths upon the black African subjects. Set in the post-civil-war America (1861-65), when the war has just ended, the novel narrates the touching experiences of the slave men and women who were living in miserable slavery. Morrison has strongly criticized in this remarkable novel, now an Afro-American classic, the callous fugitive slave act of 1850 according to which the slaves were the property of the masters and in case of escape could be taken back by the masters.

Helene Cixous's theory of Ecriture Feminine and ideas relating to phallocentrism is a bridge to reach Morrison's views in Beloved. Cixous defines the term phallocentrism as the self-admiring and self-stimulating force that can be seen in the entire history of writing where ideas put on the paper obeyed reason. Cixous (1975) points out that the writers, for long, have been glorifying reason and avoiding the language of the body and other feminine aspects which have their own importance. A close look at the definitions of logocentrism, and phallogocentrism, makes it obvious that these are only the false binaries which have categorized human beings among men and women where men are always given superiority over women due to their so-called physical and intellectual vigor. And this superiority becomes an inalienable right of males through phallocentric discourses. Freud's discussion of 'penis envy' and 'fear of castration' privileges male and his sexual prowess represented through the phallus, and conceives the relation between male and female only in binaristic terms ascribing the positive and powerful with the male gender and weaker and inferior to the female gender, or, put otherwise, constructing and describing all that is associated with women as negative and inferior while things that men do as positive and normative. According to the college of Liberal Arts at Prude's English Theory Terms webpage: "Discourse is 'phallogocentric' because it is centered and organized through-out by implicit resource to the phallus..." (Purdue, n-p).

This term that has been created by Cixous directly rejects the phallogocentric view of writing. Here Cixous does not sympathies with women only but with the human beings as they have, from time immemorial, been denied to speak their bodies. Though women have always claimed to be suppressed by men, Cixous believes that all men and women who failed to speak through their bodies due to the phallogocentric system are the real sufferers. In this way, it can be said without any shadow of a doubt that whenever a women exercise ecriture feminine, she actually embodies her thoughts and expresses them through her body. It is not her tongue that speaks rather it is her body that tells the whole story. Her tongue may be restricted due to the pressure of society but her body speaks what she thinks.

If Morrison re-tells the story of Garner in Beloved it may be called only a historical version of Margaret Garner. But the thing that distinguishes Beloved is that it returns to the body and speaks about the matter of shame and terror and especially of freedom through the body. Both Morrison and Cixous reject the idea that the mind speaks louder than the body. Rather it is interesting to observe that the canvas of the body is vaster than that of the mind as we can explore the un-named and 
unpopular people also by focusing on the bodily needs and experiences. Some critics may claim that, in the past, women spoke through their bodies also but how it came that under the suppressing hands of patriarchy, women may feel free to express their thoughts through their bodies. Within the phallogocentric culture, women may never be represented truly and properly in any society. How can they speak through their bodies when their bodies are in possession of male members of society who are always there to direct their conversation and assign them roles? It is only possible when they get back their bodies and represent themselves freely. Cixous, speaking about women's writing, invites and urges women to write about themselves and about their gender from which they have been historically and socially driven away as they have been systematically alienated from their bodies. Reconnecting with the body entails the awareness of what the body wants and the knowledge of how the (female) body has been banished. Therefore, to reclaim her body, a woman must put herself into the text - as into the world and into history - by her own movement. (Cixous, 1975).

By the same token, Morrison's purpose in writing Beloved is that she desires to bring out the repressed tales of those Black bodies which have been caught into the American chains of slavery for a long time. There are numerous examples that can be extracted from Beloved to show how the bodies speak by themselves. If the tongues remain silent, the scars on the backs of the characters in Beloved tell the whole story of oppression committed by their masters. The horrors of slavery are reflected through the breast milk and blood of Sethe. These are the bodies of Sethe and Beloved that disclose the oral and un-representable stories and never let them drown into the depth of history. Through the narrating voice of Paul, the stories of former slaves are unfolded: "White people believed that ... under every dark skin was jungle..." in which flew fast un-navigable water, and where moving screening baboons, sleeping snakes and exotic animals were prepared to pounce upon the sweet blood of the white people. He thought what the whites thought about the blacks was conversely true because "it was not the jungle the blacks brought to this place from the other (livable) place. It was the jungle white folks planted in them ..." and the screening baboons and all kind of predatory animals "lived under their own white skin" (Morrison, 1988, p. 243).

Morrison rejects the binaries between the white and colored people by suggesting the idea that the animal living inside the people is not born black rather it is the white animal, brought by the white men, that dwells among the colored ones. It is actually the projection of white bodies onto the black bodies. So the body becomes a place of projections. It also shows that it is actually the Western whitedominated phallogocentrism that has introduced darkness among the colored people as their skin may be dark due to climate but the oppressing and suppressing environment created by the white phallogocentrism has projected them as the "Others". The way Morrison and Cixous motivate us to look at women and their writings open new vistas for other marginalized people to narrate their untold stories. 
The language of body is seen in many novels of Morrison but Beloved is an exception as it speaks more conspicuously than the rest of her writings. Pecola in The Bluest Eye shouts loudly through her body but in the end she becomes insane, Hegar commits suicide in Song of Solomon, and Sula leaves the world with town falling apart. However, the story in Beloved ends in some different way as both Denver and Sethe learn how to indulge in self-love and Paul commits to take care of Sethe. The banishing of Beloved does not stop the characters from moving on. Baby Suggs' calling sermons impact the whole community to a certain point where they can find redemption. So the ideas surrounding Ecriture Feminine easily extend into the spiritual realm. This spirituality may be gained by focusing on the material and bodily objects also.

Study of Beloved from a phallogocentric and Ecriture Feminine perspective reveals that the story is not to be passed on but rather it must be told through bodies and non-phallogocentric devices. Sethe's body is the strongest body as it tells the story. Though the story of the novel starts with a house number (p. 124) with so many characters like Denver, Sethe, the ghost and Paul D but it actually begins with Sethe's memory twisted back to a past event when she is performing a sexual act in exchange for the word Beloved. This is the time when Sethe's body tells the story leading to the other actions of the novel.

Sethe's memories narrate the entrance of Paul D that eclipses the stories of a mysterious ghost, Baby Suggs, Denver and even of Sethe. It also leads to the mentioning of a tree which actually is a scar on Sethe's body/back; this tree on back is enough to tell us the horrible story of being beaten by a slave master. She says: "I had milk .... I was pregnant with Denver but I had milk for my baby girl." (Morrison, 1988, p. 19). Sethe is interrupted by Paul D, who likes to listen to the story of body (the scar of a tree on her back) and not the story of the tongue (that mentions the milk for baby girl). So, she finally starts the story after admitting to be beaten and tells the dark and depressing episode of her brutal treatment by the white boys who came and took her milk as though she were an animal while the "School teacher made one open up my back, and when it closed, it made a tree. It grows there still" (Morrison, 1988, pp. 19-20).

It is very important to note that the scar of the tree on the back of Sethe keeps on growing as her body grows which is actually the growth of the story also. The bodies may be enslaved but the process of growth can never be enslaved. The bodies are free to grow which actually means that there is a kind of freedom that is found in the bodies. In this regard, Henderson aptly comments that "The tree on Sethe's back is endemic of this process as her body functions as a template for viewing the rootedness of mental sufferings" (Henderson, 2002, p. 83).

Throughout the novel, the tale of Sethe's tree proves how all the fragmented pieces in Morrison's story come together to make a linear piece of writing. This tree not only reminds us of the story of Denver's birth but also certain experiences of slavery. The involvement of body in the story is also proved through the way milk 
from Sethe's breasts has been described telling the story of a baby ghost that will become Beloved who is hungry for her mother. Sethe's tree also describes a 'thick love' that consumes Sethe as well as Beloved and those around them. And most importantly, it narrates the story of the whole concept of slavery prevailing in Sethe's society.

Morrison pays direct heed to the words of Cixous and uses breast milk and blood and water as the "ink" of her story. This 'white ink' is seen when Sethe narrates her story and beings with: "I had milk - I was pregnant with Denver but I had milk for my baby girls" (Morrison 19). She narrates how the school teacher's boys made a sexual assault on her by coming closer to her to get milk from her boobs. Morrison, through the mouthpiece of Sethe, uses words carefully. She does not use the words like "sexual assault", "rape' or "beatings" rather she uses the language of body by saying that the men robbed women, especially the mothers by taking away something precious from the mothers - the thing that made them the mothers: "There was no nursing milk to call my own. I know what it is to be without the milk that belongs to you" (Morrison, 1988, p. 236).

Now it is important to note that Sethe's breast milk also has its symbolic significance. The rules of slavery do not allow anything in the possession of a slave. Nothing belongs to them even if it has been bestowed by nature. Everything is snatched away by the respective owner of the bodies, even the breast milk is not left for the children. But Sethe is happy to serve not only the children but also the assailants. This milk becomes a strong symbol of a thing that can be gained by freedom. The only milk that Sethe cannot get for her children becomes bad or sour for her.

Morrison applies Ecriture Feminine dynamics to criticize the Western ideology of writing. Morrison complicates the notion of time in Beloved which shows that she purposefully and successfully evades a phallogocentric linear tale. The story in Beloved does not move in a chronological order where Sethe begins with her mother and Nan, goes to Sweet Home, marries, elopes, remains with baby, kills her daughter, brings up Denver, experiences the pangs of Baby Suggs' death and meets Paul D and Beloved rather the story starts with Baby's death and then Paul D is introduced. Morrison weaves an intricate web to narrate the memories and stories of different characters. Sometimes the characters are introduced but they are explained in the latter part of the novel. Though Morrison is not the first to employ this use of time but the remarkable way she has done it promotes anti-phallogocentric narratology and opens space to tell fractured stories infractions.

\section{Conclusion}

The reading of Beloved from the Ecriture Feminine perspective leads us to draw the conclusion that language of body is as much important as other languages. We believe that the work of writing the body is included in the idea of Ecriture Feminine that makes us realize that the conventions of phallogocentric writing may 
be challenged not only through the language of body but also through inventing some more ways of writing which reject the conventional methods in terms of linearity, vocabulary, repetition etc. Morrison succeeds in extending the theory of Ecriture Feminine into other areas and by so doing she has successfully reconfigured the black history, memory, and feminine identity, among other things. She gives the alternative of hierarchy and patriarchy in the form of community. She invents language to counter the traditional phallogocentrism and also denies the spiritual and religious explanation of the centrality of man. 


\section{References}

Beauvoir, Simone de. (1989). The second sex. New York: Vintage Books.

Butler, Judith. (1993). Bodies that matter. New York: Roudedge.

Collins, Patricia Hill. (1991). Black feminist thought: knowledge, consciousness and the politics of empowerment. New York: Routledge.

(2002). Black feminist thought: knowledge, consciousness, and the politics of empowerment. London: Routledge.

Cixous, Helene. (2002). An imaginary utopia. Sexual/Textual Politics : 102-27. Print.

(1975). The laugh of the medusa. Feminisms Redux: An Anthology of Literary Theory and Criticism: 416-31. Print.

Gross, Elizabeth. (Feb. 1985). "Criticism, feminism and the institution. Thesis Eleven. vol. 10-11, no. 1, pp. 175-187, DOI:10.1177/072551368501000113.

Henderson, Carol E. (2002). Scarring the black body: race and representation in African American literature. Columbia: University of Missouri Press.

Hooks, Bell. (1981). Ain't I a woman: black women and feminism. Boston: South End Press

(2000). Feminism is for everybody: passionate politics. London: Pluto Press.

Irigaray, Luce. (1985). Speculum of the other woman. New York: Cornell University Press.

Kristeva, Julia. (1984). Revolution in poetic language. New York: Columbia University Press.

Morrison, Toni. (1988). Beloved. 1987. New York: Plume 252.

Purdue, CLA. (n.d.) Phallocentrism or phallogocentrism. College of Liberal Arts. Purdue U.

Showalter, Elaine. (1977). A literature of their own: British women novelists from Bronte to Lessing. New Jersey: Princeton University Press Princeton.

Trinh, T. Minh-Ha. (1989). Woman, native, other: Writing postcoloniality and feminism. Bloomington: Indiana University Press.

Walker, Alice. (1983). Looking for Zora. in search of our mothers' gardens: womanist prose. San Diego: Harcourt Brace Jovanovich. 